\title{
Palaeoclimatic Control on the Composition of Palaeozoic Shales from Southern Ghana, West Africa*
}

\author{
D. K. Asiedu, D. Atta-Peters, E. Hegner, A. Rocholl, and T. Shibata
}

Asiedu, D. K., Atta-Peters, D., Hegner, E., Rocholl, A. and Shibata, T. (2010), "Palaeoclimatic Control on the Composition of Palaeo zoic Shales from Southern Ghana, West Africa", Ghana Mining Journal, Vol. 12, pp. 7 - 16.

\begin{abstract}
The Late Ordovician to Early Cretaceous Sekondian Group of southern Ghana is made up of seven major sedimentary formations. One important feature of the Sekondian Group is the abundance of fairly fresh plagioclase in the lowest two formations, i.e., the Ajua Shale and Elmina Sandstone, and at the uppermost formation (i.e., Essikado Sandstone); but a virtual absence throughout the rest of the Group. The basal part of the Sekondian Group has been interpreted as of glacial origin whereas the upper formations are thought to have formed in a warmer stage. The abundant plagioclase in the lowest two formations could, therefore, be due to less pervasive chemical weathering rather than erosion of a distinct source. In this paper, geochemical data for fine-grained sedimentary rocks of the Ajua Shale and the Takoradi Shale (that overlie the Elmina Sandstone) formations are used to investigate the influence of palaeoweathering on the composition of the Sekondian Group.

The concentrations of the transition trace metals $\mathrm{Cr}, \mathrm{Ni}, \mathrm{V}$, and $\mathrm{Cu}$, and $\mathrm{Cr} / \mathrm{V}-, \mathrm{Zr} / \mathrm{Y}-$, and $\mathrm{Ba} / \mathrm{Co}-\mathrm{ratios}$ are similar in the samples from both formations and suggest that they were largely derived from the granitoids that intrude the Birimian supracrastal rocks. However, the Takoradi Shale samples are enriched in Rb, Cs, Th, U, and Nb relative to the Ajua Shale samples, and this may be related to differences in the degree of weathering in the source rocks. The Takoradi Shale samples are characterized by high chemical index of alteration (CIA) values and $\mathrm{Rb} / \mathrm{Sr}$ ratios (CIA $>75 ; \mathrm{Rb} / \mathrm{Sr}>1$ ) indicating high degrees of weathering of their source rocks. In contrast, the Ajua Shale samples have low CIA values and $\mathrm{Rb} / \mathrm{Sr}$ ratios $(\mathrm{CIA}<62 ; \mathrm{Rb} / \mathrm{Sr}<0.5)$ that indicate low degrees of weathering of their source. The tectonic setting at the time of deposition of both formations was passive margin suggesting that the change in paleoclimatic conditions rather than erosion rates played a more dominant role in the observed compositional changes in these shales.
\end{abstract}

\section{Introduction}

Studies of the geochemistry of clastic sedimentary rocks have revealed that their chemical compositions are closely related to their provenance and the tectonic setting at the time of their deposition. As a consequence, researchers have developed discrimination diagrams for the identification of provenance and tectonic settings, some of which rely heavily on the so-called mobile elements such as the alkalis and the alkaline earths (e.g., Bhatia, 1983; Roser and Korsch, 1986; 1988). However, prior to the deposition of clastic sediments, the concentrations of mobile elements may be significantly modified by processes such as chemical weathering in the source area and during transport, and diagenesis (Johnsson, 1993). Accordingly, provenance studies are now concentrated on the use of immobile elements such as the high-field strength, the rare earths, and the first transition metals because these elements are transported quantitatively from the source to the sedimentary basin and thus reflect the composition of the source rocks (Taylor and McLennan, 1985; McLennan, 1989).

However mobile elements are still useful in provenance studies because these elements (e.g., alkali

\footnotetext{
* Manuscript received October 2, 2009

Revised version accepted December 20, 2009
}

and alkaline earth elements) are rapidly removed during chemical weathering, and thus can be used to monitor the degree of chemical weathering in source regions at the time of deposition (Nesbitt and Young, 1982, 1984). Paleoweathering in the source area, therefore, is one of the most important processes affecting the composition of sedimentary rocks. In fact, the effect of paleoclimate and paleoweathering conditions often go underappreciated when interpreting the provenance and tectonic settings of sedimentary rocks (Fedo et al., 1997).

An excellent opportunity where the effect of paleoweathering on the sediment composition may be evaluated is provided by the Late Ordovician to Early Cretaceous Sekondian Group of southern Ghana (Fig. 1), which is made up of seven major sedimentary successions. An important feature of the Sekondian Group is the abundance of fairly fresh feldspar in the two basal formations, i.e., the Ajua Shale and Elmina Sandstone, and at the uppermost formation; and absence of significant amounts in the other sedimentary units. Crow (1952) has suggested that the Ajua Shale and Elmina Sandstone were deposited under cold and dry climatic conditions, respectively, whereas the upper units were deposited under warm and humid 


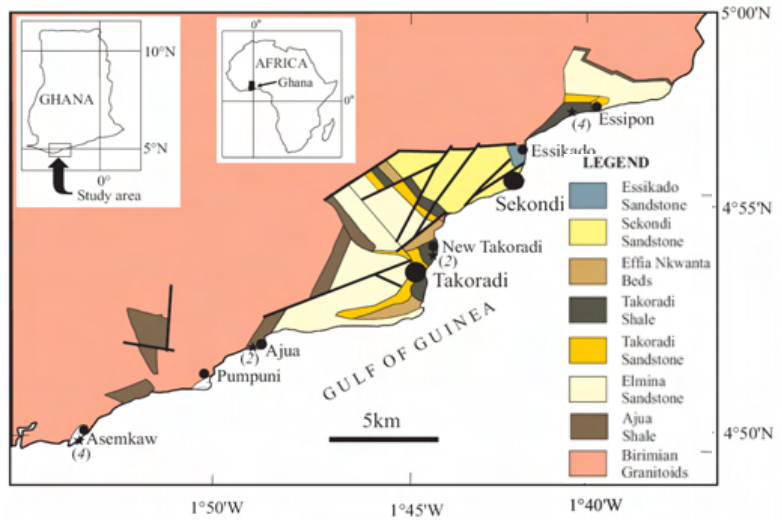

Fig. 1 Simplified Geological Map of the Sekondian Group in the SekondiTakoradi Area, Ghana (after AttaPeters, 2000). Sampled Localities are shown by Asteriks

climatic conditions. Previous provenance study on these sedimentary rocks used immobile trace elements and Nd-isotopes to infer that the rocks were derived from granitic and metasedimentary rocks of Palaeoproterozoic age (Asiedu et al., 2005). This paper focuses on mobile elements to investigate the control of paleoclimate and paleoweathering on the sediment composition of the Ajua Shale and the Takoradi Shale overlying the Elmina Sandstone (Fig. 2).

\section{Geological Background}

\subsection{The Sekondian Group}

The Late Ordovician to Early Cretaceous Sekondian Group crops out along the western and central coast of Ghana (Fig. 1). It is a $1.2 \mathrm{~km}$-thick sandstone and shale dominated succession, but also includes coarse breccias and conglomerates. The rocks are extensively faulted and virtually unmetamorphosed. The stratigraphic units of the Sekondian Group are shown in Figure 2, which also depicts the units that were sampled for this study (i.e., Ajua Shale and Takoradi Shale). The Sekondian Group rest with a profound unconformity on granitic rocks of the Palaeoproterozoic Birimian Supergroup. Provenance studies suggest that the sedimentary rocks of the Sekondian Group were largely derived from the Birimian granitoids (Asiedu et al., 2005). On the basis of Palaeontological evidence, sedimentary textures and sedimentary structures, the environment of deposition of the Group has been interpreted as non-marine to coastal marine (Crow, 1952; Atta-Peters, 1999, 2000; Asiedu et al., 2000). MicroPalaeontological data indicate deposition from Late Ordovician to Early Cretaceous (Fig. 2; Mensah, 1973; Bär and Riegel, 1980; Atta-Peters, 2000) and that it broadly correlates with the formations of the Maranhao Basin of Brazil (Bär and Riegel, 1980).
(A)

\begin{tabular}{|c|c|c|c|}
\hline Group & 豆 & $\underset{8}{*}$ & Thickness \\
\hline \multirow{7}{*}{ 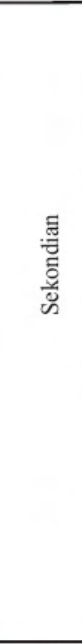 } & 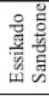 & 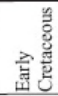 & $105 \mathrm{~m}$ \\
\hline & 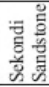 & \multirow{2}{*}{ 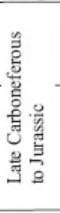 } & $200 \mathrm{~m}$ \\
\hline & 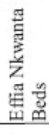 & & $210 \mathrm{~m}$ \\
\hline & 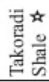 & \multirow{2}{*}{ 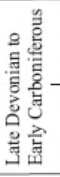 } & $200 \mathrm{~m}$ \\
\hline & 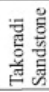 & & $180 \mathrm{~m}$ \\
\hline & 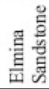 & 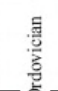 & $300-400 \mathrm{~m}$ \\
\hline & 丞的 & 年 & $60 \mathrm{~m}$ \\
\hline 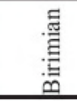 & & 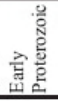 & \\
\hline
\end{tabular}

(B)

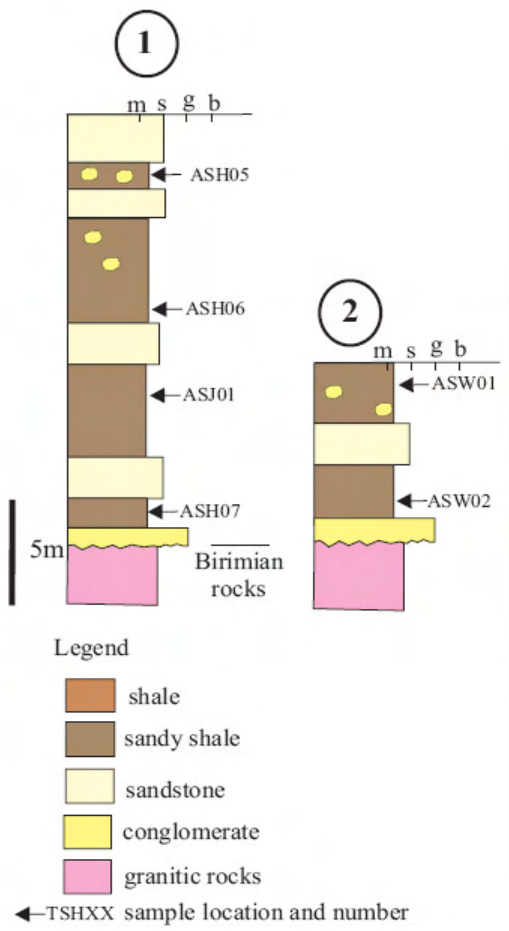

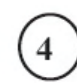
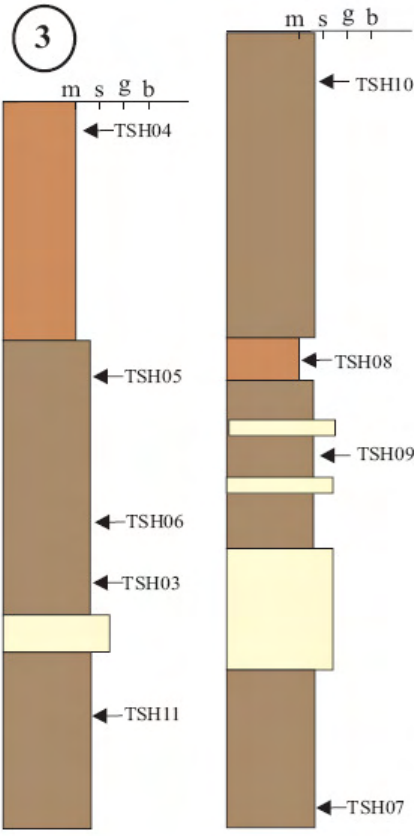

Fig. 2 (a) Stratigraphic Column of the Sekondian Group in Southern Ghana (after Bär and Riegel, 1980). Asteriks show Stratigraphic Levels from which the Samples were collected. (b). Measured Stratigraphic Sections of the Sampled Localities shown in Fig. 1 Adjacent Numbers Represent Samples collected for Geochemical Analyses. 
The Ajua Shale is about 60 meters thick and forms the basal formation of the Sekondian Group. It rest directly on the underlying crystalline rocks. Typically, the formation is composed of dark gray varved shales with alternating laminations of fine and coarse material and with beds of sandstone. Rock fragments of boulder to pebble size are scattered throughout (Fig. 3a). Feldspar crystals are abundant in the coarse laminations and in the sandstone.

The Takoradi Shale is typically composed of hard, compact, black or dark gray fissile shale or sandy shale, rich in organic matter. The base of the formation consists of alternating succession of thinbedded micaceous sandstone and gray shales. Pyrite occurs either as microscopic disseminations or as spherical nodules up to about $3 \mathrm{~cm}$ in diameter. Towards the top of the formation are large discoidal nodules of compact, finely granular, gray siderite or clay ironstone (Fig. 3b). The total thickness of the Takoradi Shale is about $200 \mathrm{~m}$.

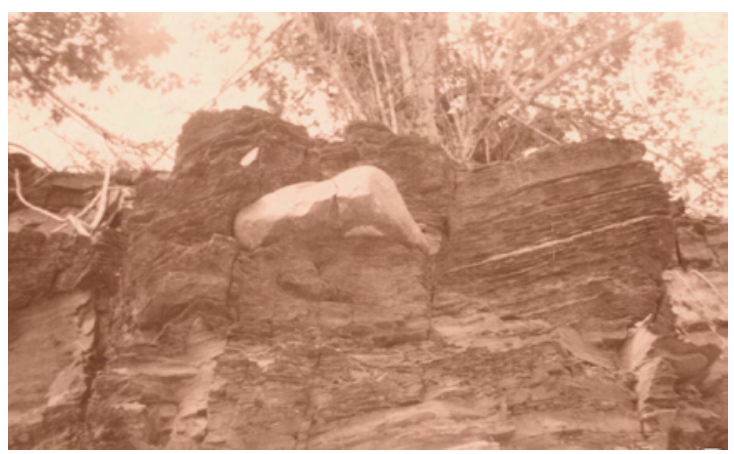

Fig. 3 (a) Photograph of an Outcrop of the Ajua Shale Formation in Asemkaw Beach that Shows a Large Isolated Granitoid Clast (ca. $1 \mathrm{~m}$ across) in Finely Bedded Shale

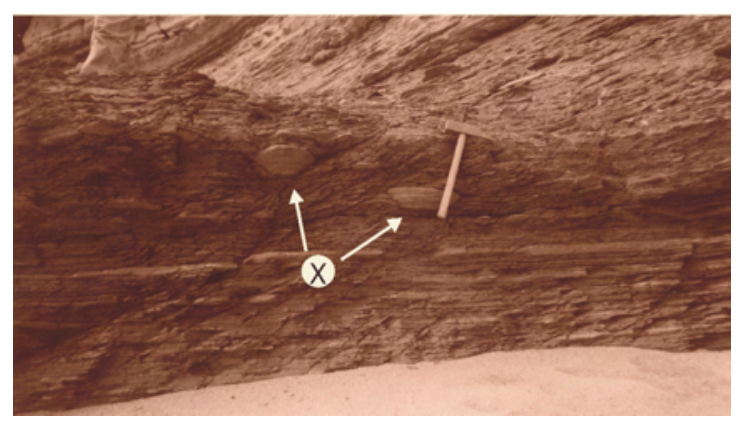

Fig. 3 (b) Photograph of the Takoradi Shale Formation in Essipon Beach that shows Finely Bedded Shale with Siderite Nodules (indicated by $x$ )

\subsection{Possible Source Rocks}

Paleocurrent directions for most of the formations of the Sekondian Group are southeasterly (Crow,
1952) and Nd-isotope model ages range from 1.6 to $2.3 \mathrm{Ga}$ (Asiedu et al., 2005), suggesting the Early Proterozoic basement rocks of Ghana as the probable source. The Early Proterozoic basement rocks of Ghana consist of Birimian and Tarkwaian rocks of the West African Craton and the Dahomeyan Formation of the Pan-African mobile belt. The Birimian crust of Ghana comprises metavolcanic belts and intervening sedimentary basins. The sedimentary basins consist of dacitic volcaniclastics, wackes and argillites whereas the volcanic belts consist predominantly of metamorphosed tholeiitic lavas and minor volcanoclastics. Both belts and basins are extensively intruded by various generations of granitoids of Early Proterozoic in age. The Tarkwaian Group represents the erosional products of the Birimian crust. The Dahomeyan formation, which appears to be Birimian rocks mobilised during the Pan African orogeny (Affaton et al., 1980), is composed of granitic and mafic gneisses, schists, and migmatites.

Various types of Palaeoproterozoic granitoids occur in Ghana. They include Cape Coast-type granitoids, Dixcove-type granitoids and Winneba-type granitoids, all within the Birimian terrane, and the granitic gneisses of the Dahomeyan Formation. The Cape Coast- and Dixcove-type granitods consist mostly of tonalities, trondhjemites and granodiorites while the Winneba-type granitoids are granodiorites and granites (Leube et al., 1990).

\section{Paleoclimatology}

Palaeontological data on the Sekondian Group indicate a Late Ordovician age for the Ajua Shale (Bär and Riegel, 1980) and a Late Devonian to Early Carboniferous age for the Takoradi Shale (Crow, 1952; Mensah, 1973; Atta-Peters, 1996, 1999). The Sekondian Group is located in the West Africa segment of the Gondwanan supercontinent (Fig. 4). Paleomagnetic and biogeographic data show that during the Late Ordovician the Gondwanan supercontinent was located in high southerly paleolatitudes, with North Africa situated on the south magnetic pole (Fig. 4). The paleoreconstructions suggest that the Ajua Shale was deposited under glacial conditions. Field evidence also supports deposition of the Ajua Shale under low-temperature conditions. The thick series of alternating coarse and fine laminations of the Ajua Shale are highly suggestive of glacial varves. In addition, the occurrence of poorly-sorted angular boulders and pebbles (dropstones?) in otherwise laminated to finely bedded sedimentary rocks also support a glacial origin. One objection to the glacial origin for the Ajua Shale is the absence of tillites and striations on boulders.

Paleomagnetic data for the Devonian of Gondwana are numerous but contradictory enough to give rise 
to diverging interpretations regarding the latitudinal position of this continent (Robardet, 2003). On the contrary, lithological indicators of paleoclimate and paleobiogeographical data are in perfect agreement and place the West Africa segment of Gondwana in temperate latitudes during the Late Devonian (Fig. 4). The Takoradi Shale is characterised by black carbonaceous (mostly composed of plant tissue; Crow, 1952) and pyritic shale containing large discoidal nodules of grey siderite or clay ironstone. The latter provides evidence of post-glacial conditions under low $\mathrm{pH}$ and negative

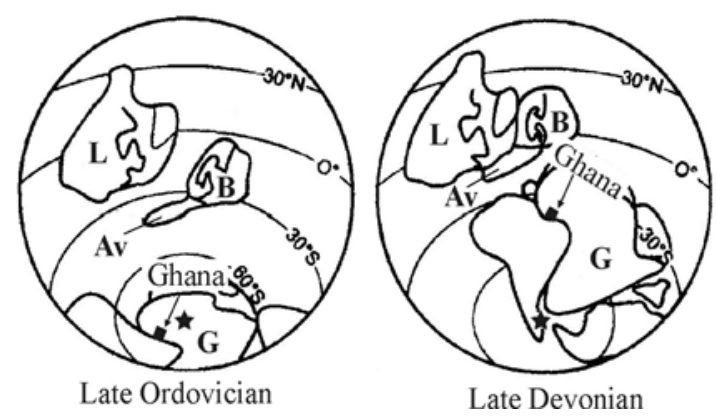

Fig. 4 Late Ordovician and Late Devonian Pa leogeography of the Present day PeriAtlantic Regions showing the position of Ghana relative to the South Pole (indicated by asterik). The Map is based on Paleoclimatic and Paleobiogeographi cal Data (after Robardet, 2003). Abbreviations: L, Laurentia; B, Baltica; G, Gondwana; Ar, Armorica; Av, Avalonia

Eh conditions. This requires a warm temperate climate to sustain a continuous influx of humic acids to maintain the reducing conditions (Wopfner, 2002). A warm paleoclimate for the Takoradi Shale is further supported by the presence of abundant pteridophytic spores that suggest deposition in a warm humid freshwater or marsh environment (Atta-Peters and Annan-Yorke, 2003).

\section{Analytical Method}

The samples were collected from outcrops exposed along the beach in the Sekondi-Takoradi area where the rocks are relatively fresh (Fig. 1). The Ajua Shale samples were collected from the towns of Asemkaw and Ajua whereas the Takoradi Shale samples were collected from Takoradi and between Essikado and Essipon (Figs. 1 and 2). The samples were washed thoroughly with distilled water to remove residue of seawater and then trimmed to remove material showing evidence of 'recent' chemical weathering.

Fifteen representative fine-grained samples, six from the Ajua Shale and nine from the Takoradi
Shale, were selected for major- and trace-element analyses. The samples were pulverised to approximately 200 mesh. Nine of the samples were analyzed for major and selected trace elements by Xray fluorescence (XRF) at the Geological Survey of Bavaria, Munich and the data is reported in Asiedu et al. (2005). Detection limits is $0.2 \%$ for $\mathrm{Na}$ and $\mathrm{Mg}$, and $0.1 \%$ or less for the other major elements. Detection limits is $50 \mathrm{ppm}$ for $\mathrm{Ba}, 15$ ppm for $\mathrm{Rb}$, and $10 \mathrm{ppm}$ or less for the other trace elements. The rest of the samples were analyzed for major and trace elements by Activation Laboratory Ltd., Ontario, Canada by ICP-MS. Detailed analytical procedures are described in Asiedu et al. (2000). In both laboratories standard and duplicate analyses were carried out in order to check that precision and accuracy were within acceptable limits.

\section{Results}

The major- and trace-element concentrations of the analysed samples are listed in Table 1. As we do not have sufficient geochemical data on detrital sediments from the Phanerozoic and Precambrian rocks of Ghana, a comparison of our data set is made against available standards, such as postArchaean Australian average shale (PAAS) and average upper continental crust estimate (UCC) (Table 1; Condie, 1993). Using the geochemical classification diagram of Herron (1988) the analysed samples from both formations can be broadly classified as shales; an exception is Sample TSH05, which plots astride the boundary between wacke and arkose and Sample TSH04 showing affinity with Fe-shale (Fig. 5). Significant chemical differences exist between the two formations. The Ajua Shale samples have higher $\mathrm{Fe}_{2} \mathrm{O}_{3}+\mathrm{MgO}$ and lower $\mathrm{TiO}_{2}$ concentrations, higher $\mathrm{SiO}_{2} / \mathrm{Al}_{2} \mathrm{O}_{3}$ ratios, and lower $\mathrm{K}_{2} \mathrm{O} / \mathrm{Na}_{2} \mathrm{O}$ ratios than the Takoradi Shale samples (Table 1; Fig. 6). One of the Takoradi Shale samples, i.e. TSH04 has high $\mathrm{Fe}_{2} \mathrm{O}_{3}$ and LOI (Table 1), apparently due to the abundance of disseminated pyrite in it. The $\mathrm{CaO}$ contents are low in samples from both formations. The Takoradi Shale samples are closer to PAAS in their major-element compositions than the Ajua Shale samples (Fig. 7).

The Takoradi Shale samples are characterised by higher abundances of high-field strength elements (HFSE) than those of the Ajua Shale and PAAS (Table 1; Fig. 8). The transition trace metal concentrations for both formations are similar and lower than in PAAS but broadly higher than in UCC (Fig. 8).

\section{Discussion}

\subsection{Paleoweathering Conditions}

Sedimentary rocks sensu stricto are composed merely of weathering products and reflect the com- 
position of weathering profiles, rather than bedrock (Lahtinen, 2000). Alteration of igneous rocks during weathering results in the depletion of alkali and alkaline earths and preferential enrichment of $\mathrm{Al}_{2} \mathrm{O}_{3}$ in sediments. Therefore, weathering histories of source areas may be evaluated by examining the concentrations of alkali and alkaline earth elements in sediments (Wronkiewicz and Condie, 1987). The bulk chemical changes that take place during chemical weathering have been used to quantify the weathering history of sedimentary rocks, primarily to understand paleoclimatic conditions (Nesbitt and Young, 1982, 1984). The chemical index of alteration $\left[\mathrm{CIA}=\mathrm{Al}_{2} \mathrm{O}_{3}{ }^{\prime} 100 /\left(\mathrm{Al}_{2} \mathrm{O}_{3}\right.\right.$ $+\mathrm{CaO}^{*}+\mathrm{Na}_{2} \mathrm{O}+\mathrm{Na}_{2} \mathrm{O}$ ), where $\mathrm{CaO}^{*}$

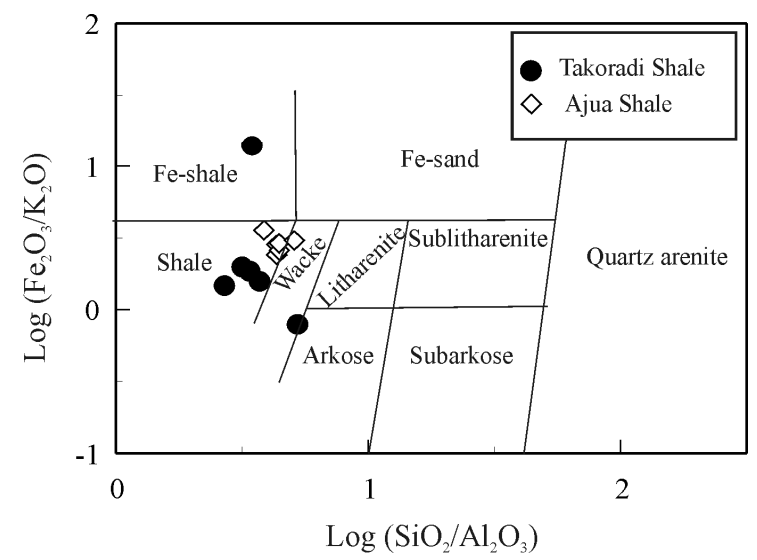

Fig. 5 Geochemical Classification of the Samples from the Ajua Shale and Takoradi Shale Formations according to their $\mathrm{SiO}_{2} /$ $\mathrm{Al}_{2} \mathrm{O}_{3}$ and $\mathrm{Fe}_{2} \mathrm{O}_{3} / \mathrm{K}_{2} \mathrm{O}$ Ratios (diagram from Herron, 1988)

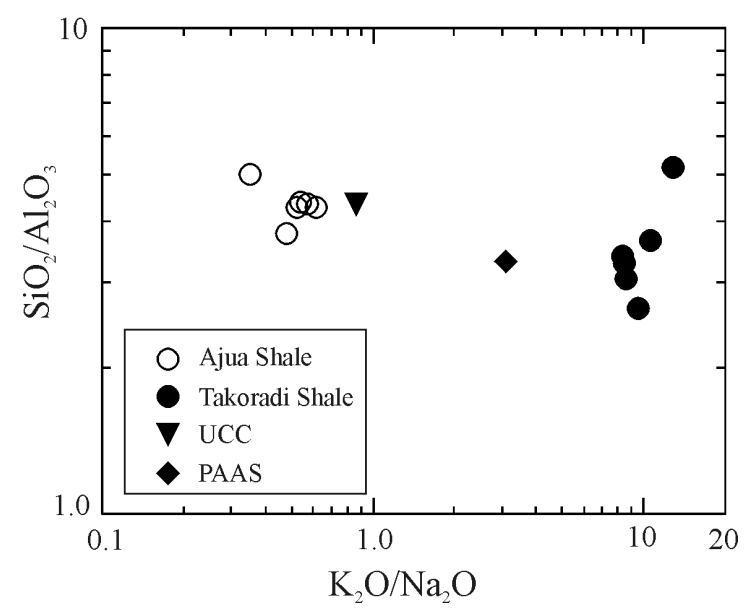

Fig. $6 \mathrm{~K}_{2} \mathrm{O} / \mathrm{Na}_{2} \mathrm{O}$ versus $\mathrm{SiO}_{2} / \mathrm{Al}_{2} \mathrm{O}_{3}$ Diagram for the Samples from Ajua Shale and Takoradi Shale Formations. Plotted for comparison are Post-Archean Australian Shale (PAAS) and Upper Continental Crust (UCC) (from Condie, 1993)

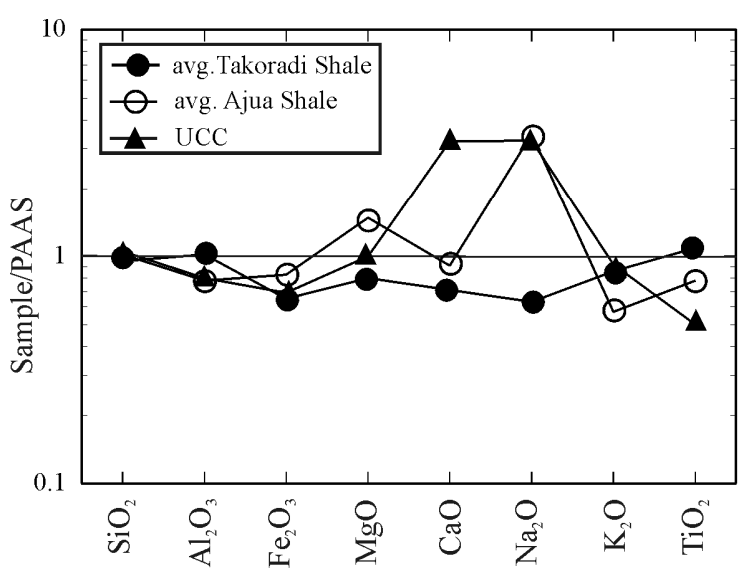

Fig. 7 PAAS-Normalized Major Element Patterns for the Average Shale Samples from the Ajua Shale and Takoradi Shale Formations. PAAS = Post-Archaean shale (Condie, 1993)

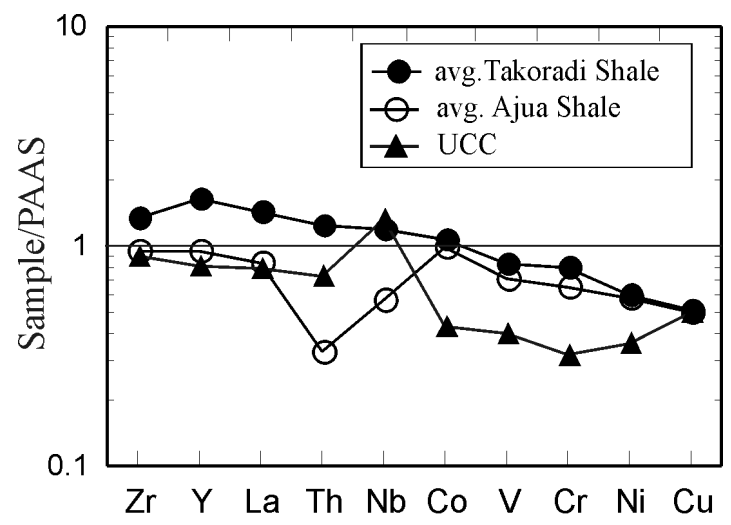

Fig. 8 PAAS-Normalised Trace Element Patterns for the Average Shale Samples from the Ajua Shale and Takoradi Shale Formations. PAAS = Post-Archaean shale (Condie, 1993)

represents $\mathrm{CaO}$ in silicate phases only; Nesbitt and Young, 1982] has been established as an indicator of the degree of weathering of sediment source area. The CIA values of the Ajua Shale samples (Table 1) are intermediate between those of unweathered igneous rocks (CIA < 50) and typical shales (CIA = 70-75; McLennan et al., 1993), suggesting that the source areas for these sediments had been only little weathered. In contrast, the Takoradi Shale samples have CIA values $\geq 75$ suggesting intense weathering of their source. The CIA may also be shown in $\mathrm{Al}_{2} \mathrm{O}_{3}-\mathrm{CaO} *+\mathrm{Na}_{2} \mathrm{O}-$ $\mathrm{K}_{2} \mathrm{O}(\mathrm{A}-\mathrm{CN}-\mathrm{K})$ compositional diagram where the data for Ajua Shale plot between the feldspar tie line and average shale (Fig. 9). This behavior may be interpreted as evidence for low degrees of weathering of their source. In contrast, the samples 
from the Takoradi Shale plot between the average composition of shale and illite, consistent with a pervasive weathering of their source (Fig. 9). Intense chemical weathering of the source area of the Takoradi Shale is further supported by the high values of their plagioclase index of alteration [PIA $>90$, where PIA $=100^{\prime}\left(\mathrm{Al}_{2} \mathrm{O}_{3}-\mathrm{K}_{2} \mathrm{O}\right) /\left(\mathrm{Al}_{2} \mathrm{O}_{3}+\right.$ $\mathrm{CaO}^{*}+\mathrm{Na}_{2} \mathrm{O}-\mathrm{K}_{2} \mathrm{O}$ ); Fedo et al., 1995]. In contrast, the Ajua Shale samples have PIA values ranging from 50 to 65 (Table 1) consistent with subordinate chemical weathering of their source.

Differences in trace element ratios are also helpful for monitoring weathering histories (McLennan et al., 1995). The $\mathrm{Rb} / \mathrm{Sr}$ ratios generally increase with increasing degrees of weathering because during weathering $\mathrm{Rb}$ is preferably incorporated into clay minerals whereas $\mathrm{Sr}$ is leached. Consequently sediment derived from sources that were significantly affected by chemical weathering, as in the case in most cratonally derived post-Archean sediments, have $\mathrm{Rb} / \mathrm{Sr}$ ratios greater than one (McLennan et al., 1995). The $\mathrm{Rb} / \mathrm{Sr}$ ratios of the Takoradi Shale samples are mostly $>1$ (Table 1) supporting the other evidence for pervasively weathered sources whereas the Ajua Shale samples have ratios $<0.5$ (Table 1) suggesting moderately weathered sources.

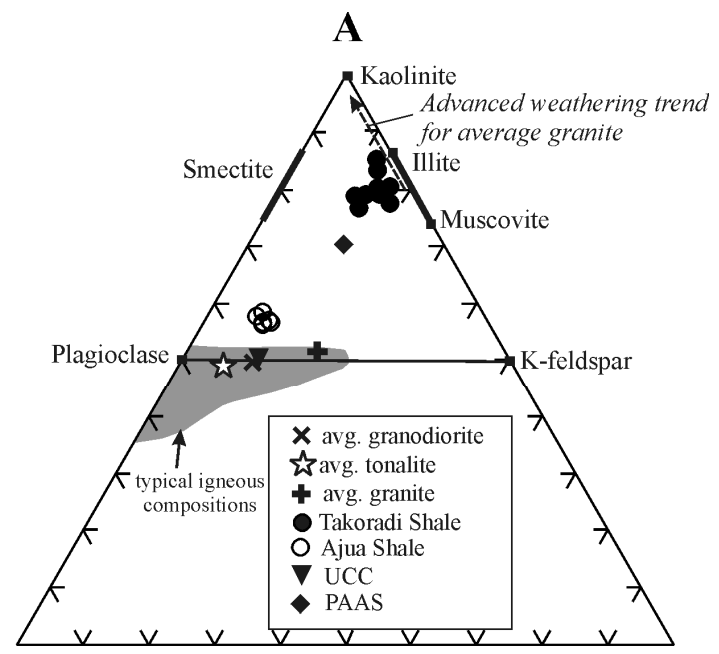

CN

Fig. 9 Ternary plot of $\mathrm{A}-\mathrm{CN}-\mathrm{K}$ for the Samples from the Ajua Shale and Takoradi Shale Formations. The Compositions of Major Minerals and Typical Rock Types are also Plotted for Comparison. Explanations: $\mathrm{A}, \mathrm{Al}_{2} \mathrm{O}_{3} ; \mathrm{CN}, \mathrm{CaO}^{*}+\mathrm{Na}_{2} \mathrm{O}$ (where $\mathrm{CaO}^{*}=\mathrm{CaO}$ in silicate phase); $\mathrm{K}, \mathrm{K}_{2} \mathrm{O}$; after Nesbitt and Young (1982). UCC, upper Continental Crust; PAAS, PostArchaean Australian Shale; Average Granite; Average Tonalite; Average Granodiorite (from Condie, 1993)
A potential problem in using geochemical indices to constrain palaeoclimates of shales is that of recycling of previously weathered detritus (Condie et al., 2001). The shales of the Ajua Shale formation are associated with sandstones rich in fresh feldspar and poor in sedimentary rock fragments. The effect of recycling of older components in the Ajua Shale Formation is, therefore, most probably minimal. In contrast, the shales of the Takoradi Shale formation are associated with moderately- to well-sorted quartz arenites (Asiedu et al., 2000) and recycling cannot be ruled out, though unlikely since the quartz grains are generally angular in shape (Asiedu et al., 2000). Another test of the maturity of the analyzed samples is the Index of Compositional Variability $\left[\mathrm{ICV}=\left(\mathrm{Al}_{2} \mathrm{O}_{3}+\mathrm{K}_{2} \mathrm{O}+\right.\right.$ $\left.\mathrm{Na}_{2} \mathrm{O}+\mathrm{CaO}+\mathrm{MgO}+\mathrm{TiO}_{2}\right) / \mathrm{Al}_{2} \mathrm{O}_{3}$; Cox et al., 1995]. Immature first cycle shales with a high percentage of non-clay silicate minerals will produce ICV values of $>1$ whereas more mature mudrocks with mostly clay minerals ought to have lower ICV values of $<1$ (Cox et al., 1995). The Ajua Shale samples have ICV values between 1.1 and 1.3 suggesting that they are compositionally immature. In contrast, the Takoradi Shale samples have average ICV value of 0.66 (range $0.47-0.86$ ), suggesting that the shales are compositionally mature and, therefore, were likely dominated by recycling. However, ICV values of $<1$ have been observed in some first cycle materials that were intensely weathered (Cullers and Podkovyrov, 2000).

\subsection{Provenance}

The chemical compositions of shales can be used to constrain their primary detrital mineralogy (Cox et al., 1995). One approach involves the use of the ratio of $\mathrm{K}_{2} \mathrm{O} / \mathrm{Al}_{2} \mathrm{O}_{3}$ (Cox et al., 1995) suggesting how much alkali feldspar versus plagioclase and clay minerals may have been present in the original shale (Cox et al., 1995). Shales samples with $\mathrm{K}_{2} \mathrm{O} / \mathrm{Al}_{2} \mathrm{O}_{3}$ ratios $>0.5$ suggest a significant quantity of alkali feldspar relative to other minerals in the original shales; those with $\mathrm{K}_{2} \mathrm{O} / \mathrm{Al}_{2} \mathrm{O}_{3}$ ratios < 0.4 suggest minimal alkali feldspars in the original shale (Cox et al., 1995). The $\mathrm{K}_{2} \mathrm{O} / \mathrm{Al}_{2} \mathrm{O}_{3}$ ratios of the Ajua Shale samples range from 0.12 to 0.16 (average $=0.14$ ) and those of the Takoradi Shale samples range from 0.14 to 0.23 (average $=0.17$ ), suggesting only small amounts of alkali feldspar in the original shale.

A number of studies have demonstrated that the immobile HFSE as well as transition metals represent useful geochemical tools to place constraints on the composition of the provenance of sediments (e.g., Taylor and McLennan, 1985; Bhatia and Crook, 1986; McLennan, 1989). Elements concentrated in mafic rocks (e.g., $\mathrm{Sc}, \mathrm{Cr}, \mathrm{Ni}, \mathrm{Co}, \mathrm{V}$ ) and elements concentrated in felsic rocks (e.g., La, $\mathrm{Zr}$, $\mathrm{Th}$ ), have been used for inferring provenance and 
tectonic setting determinations of mudrocks (e.g., Cullers, 2000). Compared to PAAS the Ajua Shale and the Takoradi Shale samples show slight enrichment of HFSE relative to the transition metals suggesting that the sediments were derived from a predominantly felsic source (Fig. 8). However, for both of the studied formations Ni positively correlates with other ferromagnesian trace elements such as $\mathrm{Cr}, \mathrm{Co}, \mathrm{V}$ and $\mathrm{Cu}$ (not shown) suggesting small contribution from a mafic source.

Elemental ratios such as $\mathrm{Cr} / \mathrm{V}, \mathrm{Zr} / \mathrm{Y}$, and $\mathrm{Ba} / \mathrm{Co}$ are considered to be least susceptible to modification by secondary processes (Wronkiewicz and Condie, 1987; Cullers et al., 1988) and are, therefore, critical of provenance studies particularly in cases where trace element fractionation by source area weathering is suspected. It can be seen that the $\mathrm{Cr} / \mathrm{V}, \mathrm{Zr} / \mathrm{Y}$, and $\mathrm{Ba} / \mathrm{Co}$ ratios are not drastically different between the Ajua Shale $(\mathrm{Cr} / \mathrm{V}, 0.59$ $-0.75 ; \mathrm{Zr} / \mathrm{Y}, 5.0-10.1 ; \mathrm{Ba} / \mathrm{Co}, 15.2-53.4)$ and the Takoradi Shale (Cr/V, 0.51-0.83; Zr/Y, 4.7-8.4; $\mathrm{Ba} / \mathrm{Co}, 18.3-48.2$ ) samples suggesting that they were derived predominantly from the same source terrane. Moreover, these ratios are fairly similar to those observed in the Birimian granitoids but significantly different from those of the Birimian volcanics (Leube et al., 1990). Furthermore, the Birimian volcanic and sedimentary rocks generally exhibit significantly lower $\mathrm{Zr}$ and $\mathrm{Th}$ concentrations, and higher $\mathrm{Cr}, \mathrm{Ni}$, and $\mathrm{V}$ concentrations (Sylvester and Attoh, 1992; than the samples of the Takoradi Shale and Ajua Shale. Nd-isotopic studies indicate that the shales of both formations were derived from Palaeoproterozoic sources (Asiedu et al., 2005). Measured $143 \mathrm{Nd} / 144 \mathrm{Nd}$ values of samples from the Ajua Shale and the Takoradi Shale (Asiedu et al., 2005) are similar to $143 \mathrm{Nd} / 144 \mathrm{Nd}$ values reported for the Birimian rocks (Taylor et al., 1992). However, the $147 \mathrm{Sm} / 144 \mathrm{Nd}$ values of the Ajua Shale and Takoradi Shale formations are significantly lower than those of the Birimian volcanics but similar to the Birimian granitoids and the sediments (Taylor et al., 1992; Asiedu et al., 2005).

If the assumption is correct that both the Ajua Shale and Takoradi Shale samples were derived from the same sources then there is the need to explain the significant differences in their LILE and HFSE abundances (Table 1; Fig. 8). Chemical weathering processes may decouple trace elements that behave coherently in igneous rocks. For example, Rb, Cs, Ba, Th, U, Ta, Nb, and REEs tend to be fixed in clays and sedimentary rocks with high proportion of clays from weathering tends to be enriched in these elements (Feng et al., 1993). According to the CIA values, the intensity of chemical weathering or alteration in the provenance area of the Ajua Shale was less than in that of the Takoradi Shale. Thus the latter should con- tain less lithic fragments and more clay minerals. The higher concentrations of $\mathrm{Rb}, \mathrm{Cs}$, Th, U, and $\mathrm{Nb}$, in Takoradi Shale samples than those of the Ajua Shale samples are consistent with different extents of weathering in their source areas. The enrichment of LILE and HFSE in the Takoradi Shale samples relative to those of the the Ajua Shale samples could therefore be explained by changes in provenance weathering rather than significant changes in provenance bedrock compositions.

\subsection{Palaeoclimate versus Tectonic Setting Con- trol on Shale Composition}

Apart from palaeoclimate the degree of source area weathering is also related to erosion, which is high in tectonically active areas. Chemical weathering tends to be less intense in tectonically active areas, where rapid uplift maintains steep slopes that work to reduce the time rocks are exposed to weathering and thus inhibiting extensive weathering even in high rainfall tropical conditions (Johnsson, 1993). For example, recent erosional products from volcanic islands in equatorial regions of the southwest Pacific Ocean have CIA values that average about 55 (McLennan et al., 1993).

Sedimentary rocks with low CIA and high ICV values $(\mathrm{CIA}<60$; ICV $>1)$ are mainly derived from active arc settings whereas those with high $\mathrm{CIA}$ and low ICV values $(\mathrm{CIA}>75$; ICV $<1)$ are derived from passive margins and cratons (Gao and Wedephol, 1995; Cullers and Podkovyrov, 2000). Accordingly, the samples from the Ajua Shale Formation (CIA, 57-59; ICV, 1.08 - 1.27) may have been deposited under tectonically active settings where rapid uplift maintained steep slopes whereas the Takoradi Shale samples (CIA, 76-85; ICV, $0.47-0.86$ ) may have been deposited in craton of quiescent environment where slopes were gentler/flat. However, the general lack of Phanerozoic volcanic rocks in West Africa and the absence of volcanic fragments in the analyzed samples do not support the active margin interpretation for the Ajua Shale Formation. Moreover, there is no direct field evidence to support the occurrence of tectonic uplifts in southern Ghana during the early Palaeozoic times; the age of the numerous faulting observed in the study area (Fig. 1) Jurassic (Crow, 1952) and is most probably related to the commencement of the rift between South America and the African continent in Aptian to Albian times (Attoh et al., 2004). It therefore appears most likely that paleoclimate rather than high rates of erosion played a dominant role in producing immature detrital materials for the Ajua Shale Formation. The arc signatures observed in the geochemistry of Ajua Shale samples may, therefore, reflect the bedrock compositions of their dominant source rocks (i.e., Birimian granitoids) that show juvenile 
features (Doumbia et al., 1998) whereas the Takoradi Shale samples were predominantly derived from the intensely weathered profile of these granitoids. Thus the higher compositional maturity of the Takoradi Shale samples relative to the Ajua Shale samples reflect the increase in the intensity of paleoweathering conditions that is dominantly the result of change in paleoclimatic conditions, i.e., from cold to tropical humid climate.

\section{Conclusions}

The geochemical features of shale samples from the Ajua Shale and the Takoradi Shale formations suggest their derivation from a provenance comprised dominantly of felsic rocks with only a minor component of mafic rocks. The inferred source lithology of these sediments favors the Palaeoproterozoic granitoid complex of the Birimian Supergroup as being their main source. The samples of the Takoradi Shale formation are characterised by high CIA and PIA values, and high $\mathrm{Rb} / \mathrm{Sr}$ ratios that suggest pervasively weathered sources. In contrast, low CIA and PIA values, $\mathrm{A}-\mathrm{CN}-\mathrm{K}$ relationships, and low $\mathrm{Rb} / \mathrm{Sr}$ ratios in shales of the Ajua Shale formation are consistent with little weathered sources, supporting a high latitude location of the West African segment of Gondwana during the Late Ordovician. It may be concluded that the geochemistry of fine-grained siliclastic materials can contribute to solving problems related to paleoclimatology and provenance.

\section{Acknowledgements}

Financial support for this project was provided by Alexander von Humboldt Foundation to D. K. Asiedu. We thank Peter Dulski of GeoForschungsZentrum, Postam, for the ICP-MS analysis. The additional samples analyzed at the Activation Laboratory Ltd. in Ontario, Canada, were financed by the Japan Society for the Promotion of Science (JSPS) Grant-in-Aid.

\section{References}

Affaton, P., Sougy, J., and Trompette, R. (1980), "The tectono-stratigraphic relationships between the Upper Precambrian and Lower PalaeozoicPalaeozoic Volta Basin and the PanAfrican Dohomeyide orogenic belt (West Africa)", American Journal of Science, 280, pp. 224-248.

Asiedu, D. K., Suzuki, S., Nogami, K. and Shibata, T. (2000), "Geochemistry of Lower Cretaceous sediments, Inner Zone of Southwest Japan: Constraints on provenance and tectonic environment", Geochemica Journal, 34, pp. 155173.

Asiedu, D. K., Atta-Peters, D., and Peprah, R.
(2000), "Depositional environment of the Takoradi Sandstone formation of the Sekondian Group, western Ghana, as revealed by textural analysis", Ghana Mining Journal, 6, pp. 53-58.

Asiedu, D. K., Hegner, E., Rocholl, A., and AttaPeters, D. (2005), "Provenance of Late Ordovician to Early Cretaceous sedimentary rocks from southern Ghana, as inferred from $\mathrm{Nd}$ isotopes and trace elements", Journal African Earth Science, 41, pp. 316-328.

Atta-Peters, D. (1996), "Latest Devonian and Early Carboniferous miospores from the Takoradi Shale Formation of the Sekondian Group, Western Ghana", African Geoscience Review, 3, pp. 413-427.

Atta-Peters, D. (1999), "Upper Devonian acritarchs from the Lower Takoradi Shales of the Sekondian Group", Ghana Mining Journal, 5, pp. $1-10$.

Atta-Peters, D. (2000), "Early Cretaceous miospores from the Essikado Sandstone Formation of the Sekondian Group of Ghana", Revista Espanola de Micropaleontologia 32, pp. 245257.

Atta-Peters, D., and Anan-Yorke, R. (2003), "Latest Devonian and Early Carboniferous pteridophytic spores from the Sekondi Group of Ghana", Revista Espanola de Micropaleontologia, 35, pp. 9 - 27.

Attoh, K., Brown, L., Guo, J., and Heanlein, J. (2004), "Seismic stratigraphic record of transpression and uplift on the Romanche transform margin, offshore Ghana", Tectonophysics 378 , pp. $1-16$.

Bär, P., and Riegel, W. (1980), "Latest Ordovician to Earliest Silurian microfloras from the Lower Sekondi Series of Ghana (W Africa) and their relation to those from the Itaim Formation of the Maranhao Basin in NE Brazil", N. Jb. Geol. Paläont. Abh. 160, pp. 42-60 (in German with English abstract).

Bhatia, M. R. (1983), "Plate tectonics and geochemical composition of sandstones", Journal of Geology 91, pp. 611-627.

Bhatia, M. R., and Crook, K. A. W. (1986), “Trace element characteristics of greywackes and tectonic setting discrimination of sedimentary basins", Contributions in Mineralogy and Petrology 92, pp. 181-193.

Bock, B., McLennan, S. M., and Hanson, G. N. (1998), "Geochemistry and provenance of the Middle Ordovician Austin Glen Member (Normanskill Formation) and the Taconian Orogeny in New England", Sedimentology, 45, pp. $635-655$.

Condie, K. C. (1993), "Chemical composition and evolution of the upper continental crust: contrasting results from surface samples and shales", Chemical Geology, 104, pp. 1- 7.

Condie, K. C., Lee, D., and Farmer, G. L. (2001), 
"Tectonic setting and provenance of the Neoproterozoic Uinta Mountain and Big Cottonwood groups, northern Utah: constraints from geochemistry, $\mathrm{Nd}$ isotopes, and detrital modes", Sedimentary Geology, 141-142, pp. 443-464.

Cox, R., Low, D. R., and Cullers, R. L. (1995), "The influence of sediment recycling and basement composition on evolution of mudrock chemistry in the southwestern United States", Geochimica et Cosmochimca Acta, 59, pp. 2919-2940.

Crow, A. T. (1952) The Rocks of the Sekondi Series of the Gold Coast, Gold Coast Geological Survey Bulletin No. 18, William Lewis Ltd., Cardiff., pp. 40

Cullers, R. L. (2000), "The geochemistry of shales, siltstones, and sandstones of PennsylnanianPermian age, Colorado, USA: implications for provenance and metamorphic studies", Lithos 51, pp. 181-203.

Cullers, R. L., and Podkovyrov, V. N. (2000), "Geochemistry of the Mesoproterosoic Lakhanda shales in southern Yakutia, Russia: implications for mineralogical and provenance control, and recycling", Precambrian Research, 104, pp. 77-93.

Cullers, R. L., Basu, A., and Suttner, L. J. (1988), "Geochemical signature of provenance in sandsize material in soils and stream sediments near the Tobacco Root Batholith, Monata, U.S.A", Geochimica et Cosmochimca Acta, 63, pp.1 285-1301.

Doumbia, S., Pouclet, A., Kouamelan, A., Peucat, J. J., Vidal, M., and Delor, C. (1998), "Petrogenesis of juvenile-type Birimian (Palaeoproterozoic) granitoids in Central Côted'Ivoire, West Africa: geochemistry and geochronology", Precambrian Research, 87, pp. $33-63$.

Fedo, C. M., Nesbitt, H. W., and Young, G. M. (1995), "Unravelling the effects of potassium metasomatism in sedimentary rocks and paleosols, with implications for paleoweathering conditions and provenance", Geology 23, pp. 921924.

Fedo, C. M., Young, G. M.., and Nesbitt, H. W. (1997), "Paleoclimatic control on the composition of the Palaeoproterozoic Serpent Formation, Huronian Supergroup, Canada: a greenhouse to icehouse transition", Precambrian Research, 86, pp. 201-223.

Feng, R., Kerrich, R., and Maas, R. (1993), "Geochemical, oxygen, and neodymium isotope compostions of metasediments from the Abitibi greenstone belt and Pontiac Subprovince, Canada: Evidence for antient crust and Archean terrane juxtaposition", Geochimica et Cosmochimca Acta, 57, pp. 641658.
Gao, S., and Wedepohl, K. H. (1995), "The negative Eu anomaly in Archean sedimentary rocks: implications for decomposition, age and importance of their granitic sources", Earth and Planetary Science Letters, 133, pp. 81-94.

Herron, M. M. (1988), “Geochemical classification of terrigeneous sands and shales from core or log data", Journal of Sedimentary Petrology, 58, pp. 820-829.

Johnsson, M. J. (1993), “The system controlling the composition of clastic sediments, Processes Controlling the Composition of Clastic Sediments (Johnsson, M. J., and Basu, A., eds.)", Geological Society of America Special Papers, 284, pp. 1-19.

Lahtinen, R. (2000), “Archaean -Proterozoic transition: geochemistry, provenance and tectonic setting of metasedimentary rocks in central Fennoscandian Shield, Finland", Precambrian Research, 104, pp. 147-174.

Leube, A., Hirdes, W., Mauer, R., and Kesse, G. O. (1990), "The Early Proterozoic Birimian Supergroup of Ghana and some aspects of its associated gold mineralization", Precambrian Research, 46, pp. 139-165.

McLennan, S. M. (1989), "Rare earth elements in sedimentary rocks: Influence of provenance and sedimentary processes", Mineral. Soc. Am. Rev. Mineral. 21, pp. 169-200.

McLennan, S. M., Hemming, S., McDaniel, D. K., and Hanson, G. N. (1993), "Geochemical approaches to sedimentation, provenance, and tectonics. Processes Controlling the Composition of Clastic Sediments (Johnsson, M. J., and Basu, A., eds.)", Geological Society of America Special Papers, 284, pp. 21-40.

McLennan, S. M., Hemming, S. R, Taylor, S. R., and Eriksson, K. A. (1995), "Early Proterozoic crusral evolution: Geochemical and $\mathrm{Nd}-\mathrm{Pb}$ isotopic evidence from metasedimentary rocks, southern North America", Geochimica ct Cosmochimca Acta, 59, pp. 1153-1177.

Mensah, M. (1973), "On the question of the age of the Sekondi Series, Upper Devonian or Lower Carboniferous rocks of Ghana", Ghana Journal of Science, 13, pp. 134-139.

Nesbitt, H. W. M., and Young, G. M. (1982), "Early Proterozoic climates and plate motions inferred from major element chemistry of lunites". Nature, 299, pp. 715-717.

Nesbitt, H. W. M., and Young, G. M. (1984), "Prediction of some weathering trends of plutonic and volcanic rocks based on thermodynamic and kinetic considerations", Geochimica et Cosmochimca Acta, 48, pp. 1523-1534.

Robardet, M. (2003), “The Armorica 'microplate': fact or fiction? Critical review of the concept and contradictory palaeobiogeographical data", Palaeogeo. Palaeoclimat. Palaeoecol. 195, pp. 125-148. 
Roser, B. P., and Korsch, R. J. (1986), "Determination of tectonic setting of sandstone mudstone suites using $\mathrm{SiO}_{2}$ content and $\mathrm{K}_{2} \mathrm{O}$ / $\mathrm{Na}_{2} \mathrm{O}$ ratio", Journal of Geology, 94, pp. 635650.

Roser, B. P., and Korsch, R. J. (1988), "Provenance signatures of sandstone-mudstone suites determined using discrimination function analysis of major-element data", Chem. Geol. 67, pp. 119-139.

Sylvester, P. J., and Attoh, K. (1992). "Lithostratigraphy and composition of $2.1 \mathrm{Ga}$ greenstone belts of the West African Craton and their bearing on crustal evolution and the Archaean-proterozoic boundary", Journal of Geology, 100, pp. 377-393.

Taylor, S. R., and McLennan, S. M. (1985), The Continental Crust: Its Composition and Evolution, Oxford, Blackwell Scientific, 312 p.

Taylor, P. N., Moorbath, S., Luebe, A., and Hirdes, W. (1992), "Early Proterozoic crustal evolution in the Birimian of Ghana: constraints from geochronology and isotope geochemistry", Precambrian Research, 56, pp. 97-111.

Wopfner, H. (2002), “Tectonic and climatic events controlling deposition in Tanzanian Karoo basins", Journal of African Earth Science, 34, pp. $167-177$.

Wronkkiewicz, D. J., and Condie, K. C. (1987), "Geochemistry of Archean shales from the Witwatersrand Supergroup, South Africa: source area weathering and provenance", Geochimica et Cosmochimca Acta, 51, pp. 24012416.

\section{Authors}

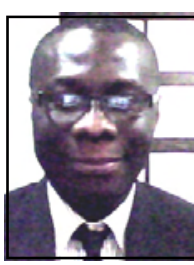

Daniel Asiedu is an Associate Professor of Geology specializing in sedimentary geology and geochemistry, with particular interest in provenance of siliciclastic sedimentary rocks. He has about 12 years' university teaching and research experience and has undertaken several extension activities mostly in the areas of education, research and consultancy services. He holds a BSc (Ghana), MSc (Okayama), and $\mathrm{PhD}$ (Okayama) degrees in Geology. He also holds a Postgraduate Certificate in Offshore Prospecting. His current research activities focus on three main areas: (1) petrology and geochemistry of siliciclastic sedimentary rocks; (2) geochemistry and petrogenesis of igneous rocks, and (3) hydrochemical and water quality studies in sedimentary and crystalline basement rocks. Research activities in these areas have resulted in over 40 peer reviewed publications. He has also attended over 20 local and international conferences where findings of his research were presented

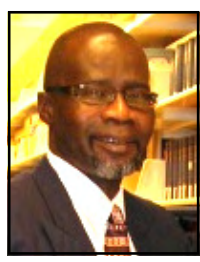

David Atta-Peters is an Associate Professor in the Department of Earth Science, University of Ghana where he teaches courses in Sedimentary Geology and Petroloeum Geoscience. He is a Fulbright Fellow and Associate of American Association of Stratigraphic Palynologists (AASP) Centre for Excellence in Palynology, Louisiana State University in Baton Rouge, USA. His research interest is in palynology, palynofacies, paleoenvironment and sedimentology of sedimentary basins. He has worked extensively on sediments from the Sekondi Group and on exploratory oil wells from the offshore Tano Basin. He is a member of American Association of Stratigraphic Palynologists (AASP), International Commission of the Palaeozoic Microflora (CIMP) and the Ghana Institution of Geoscientists (GhIG).

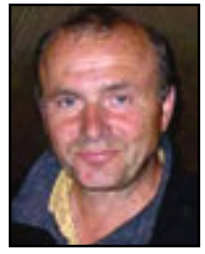

Ernst Hegner studied Geology and Paleontology at the Universities of Mainz (Germany) and Natal (Pietermaritzburg, South Africa). His Ph.D. work was carried out at the MaxPlanck-Institut für Chemie in Mainz (Geochemistry Section). From 1983 to 1986 , he was a Postdoctoral fellow at the U.S. Geological Survey in Denver and the Colorado School of Mines, Golden. Until 1990, he was a NSERC-sponsored researcher at the University of Saskatchewan in Saskatoon and at the Geological Survey of Canada, Ottawa. Thereafter, he lectured at the University of Tübingen. Since 1999, he is a Professor of Geochemistry at the University of Munich and the Head of the Isotope Laboratory, Department of Earth and Environmental Sciences. His research interests include (1) Deciphering the influence of plate tectonics and other geological processes on the chemical composition and evolution of the Earth's mantle, the continental and oceanic crust, and seawater (2) Determination of the age and duration of igneous and metamorphic events. (3) Application of isotopic data to archaeometric and environmental research, and (4) Analytical methods for measuring isotopic abundances and concentrations of elements.

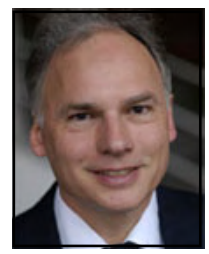

Alexander Rocholl is a Research Scientist and Manager of the isotope laboratory $(\mathrm{Nd}$, $\mathrm{Sr}, \mathrm{Pb})$ at the Department of Earth and Environmental Sciences, University of Munich. His area of research is in isotope geochemistry. His PhD work, on development of a new Sparc Source Mass Spectrometric method and application to chondritic meteorites, was carried out at the Max-Planck-Institut für Chemie in Mainz. He has also worked as research scientist and/or isotope laboratory manager at University of Mainz (1991), University of Karlsruhe (1992 - 1994), University of Heidelberg (1994 1998), and GeoForschungsZentrum Potsdam (1999 - 2001).

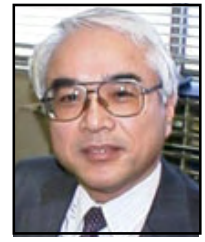

Tsugio Shibata is a Professor of Geology in the Department of Earth science, Okayama University. His main research interest is in understanding basaltic magmatism that takes place at various tectonic settings (i.e., midoceanic ridges, oceanic hot spots, and island arcs); in particular, he investigates the magmatic processes that lead to creation of oceanic lithosphere by sea-floor spreading at mid-oceanic ridges and back-arc basins. Current programs focus on the southern East Pacific Rise, Mariana Trough, Hawaiian Islands, Indian Ridge, and the inner zone of Southwest Japan. In collaboration with other researchers, he also conducts provenance studies on sedimentary rocks. 